\title{
Pengembangan website berbasis blended learning dengan materi bangun ruang sisi lengkung kelas IX SMP
}

\author{
Fitria Ayu Wulansari, Mimiep Setyowati Madja*, Mohamad Yasin \\ Universitas Negeri Malang, Jl. Semarang No. 5 Malang, Jawa Timur, Indonesia \\ *Penulis korespondensi, Surel: mimiep.setyowati.fmipa@um.ac.id
}

Paper received: 01-11-2021; revised: 15-11-2021; accepted: 30-11-2021

\begin{abstract}
Abstrak
Dunia pendidikan pada saat ini telah berada pada abad pengetahuan (abad 21). Salah satu unsur pembelajaran abad 21 yaitu menekankan pada pengembangan keterampilan belajar. Pengembangan keterampilan terkait informasi dan komunikasi salah satunya dapat guru ciptakan dengan mengembangkan pembelajaran berbasis blended learning. Website berbasis blended learning dengan materi bangun ruang sisi lengkung kelas IX SMP menggunakan perangkat open source moodle versi 2.2. Materi bangun ruang sisi lengkung ditampilkan dalam bentuk web page. Model pengembangan yang digunakan dalam penelitian ini adalah pengembangan Thiagarajan (4D) yang terdiri dari: define, design, develop, dan dissiminate, tetapi tanpa tahap dissiminate. Berdasarkan hasil angket validasi tersebut dapat disimpulkan bahwa website berbasis blended learning dengan materi bangun ruang sisi lengkung kelas IX SMP termasuk kriteria valid/ layak digunakan sebagai alternatif website dalam pembelajaran matematika.
\end{abstract}

Kata kunci: Website; Blended Learning; Bangun Ruang Sisi Lengkung; Kelas IX SMP

\section{Pendahuluan}

Menjadi bangsa yang maju tentu merupakan cita-cita yang ingin dicapai oleh setiap negara di dunia. Salah satu faktor yang mendukung kemajuan dunia adalah pendidikan. Dunia pendidikan pada saat ini telah berada pada abad pengetahuan (abad 21), yaitu abad yang berbasis TI (Teknologi dan Informasi) disegala aspek kehidupan. Menurut Susilo (2011) salah satu unsur pembelajaran abad 21 yaitu menekankan pada pengembangan keterampilan belajar. Guru memerlukan pengembangan keterampilan belajar yang terdiri dari 3 keterampilan, yaitu 1) keterampilan terkait informasi dan komunikasi; 2) keterampilan berpikir dan memecahkan masalah; dan 3) keterampilan interpersonal dan keterampilan mengatur diri sendiri. Keseluruhan ketrampilan tersebut harus diaplikasikan ke dalam proses pengajaran di kelas secara sengaja, strategis, dan seluas-luasnya.

Pengembangan keterampilan terkait informasi dan komunikasi salah satunya dapat guru ciptakan dengan mengembangkan pembelajaran berbasis blended learning. Menurut Kusairi (2011) blended learning merupakan inovasi pemanfaatan teknologi komputer dan informatika. Pada prinsipnya blended learning mengkombinasikan pembelajaran berbasis internet (E-learning) dengan pembelajaran tatap muka (face to face). Selain itu blended learning dapat melatih kemampuan siswa untuk beradaptasi dengan pembelajaran berbasis internet. Menurut Pragaswati (2012) blended learning adalah pembelajaran yang memadukan pembelajaran tatap muka di kelas dengan pembelajaran online.

Dalam pembelajaran secara online salah satu alat pendukung yang harus terpenuhi adalah ketersediaan internet. Setelah melakukan observasi, pemanfaatan internet di SMP Negeri 3 Malang dirasa masih kurang untuk menunjang pembelajaran khususnya pembelajaran matermatika. Salah satu cara yang dapat digunakan untuk pengoptimalan internet dalam pembelajaran adalah penerapan website berbasis blended learning. Website 
berbasis blended learning dapat membantu guru dalam penyampaian materi sehingga siswa dapat dengan mudah memahami materi yang diberikan oleh guru. Materi yang sulit dipahami akan menjadi mudah untuk dipahami dan suasana belajar yang menegangkan akan menjadi menyenangkan.

Pembangunan dan pengembangan website saat ini sangat mudah dilakukan karena adanya perangkat lunak Learning Management System (LMS) yang disebut moodle. Menurut Pragaswati (2012) moodle (Modular Object Oriented Dynamic Learning Environtment) adalah sebuah nama untuk program aplikasi yang dapat menyajikan sebuah website ke dalam bentuk web. Penggunakan moodle dapat memudahkan kita dalam membuat modul dan LKS. Selain itu dengan menggunakan moodle kita dapat memperkaya sumber belajar secara konvensional sehingga dapat menjawab segala tantangan globalisasi. Dengan menggunakan konsep ini maka belajar mengajar tidak akan terbatas pada ruang dan waktu.

Menurut Setyaningsih (2009:3) dalam hal belajar matematika pada dasarnya merupakan belajar konsep. Salah satu cabang matematika yang memuat banyak konsep di dalamnya adalah geometri, khususnya tabung, kerucut, dan bola. Materi bangun ruang sisi lengkung diberikan di kelas IX SMP, di mana siswa hanya memiliki sedikit waktu untuk mempelajarinya dikarenakan siswa sudah disibukkan dengan persiapan menghadapi ujian nasional sehingga pemberian materi bangun ruang sisi lengkung ini dilakukan sangat cepat oleh guru. Penyampaian materi yang terlalu cepat dapat menyebabkan penyampaian konsep yang kurang mendalam. Pembelajaran dengan menggunakan website ini akan sangat membantu siswa dalam mempelajari materi bangun ruang sisi lengkung karena siswa dapat mengakses bahan-bahan belajar kapan saja dan di mana saja. Selain itu siswa juga dapat berkomunikasi dengan guru setiap saat, misalnya melalui chatting dan email. Mengingat sumber belajar yang sudah dikemas secara elektronik dan tersedia untuk diakses melalui internet, maka siswa dapat melakukan interaksi dengan sumber belajar kapan saja dan dari mana saja.

Untuk menghadapi ujian nasional siswa membutuhkan banyak berlatih mengerjakan soal-soal. Di dalam produk yang dihasilkan banyak memuat latihan-latihan soal yang bervariasi sehingga dapat meningkatkan kemampuan siswa dalam menyelesaikan suatu soal. Produk tersebut dilengkapi dengan forum diskusi dan chat room yang dapat digunakan siswa untuk berkomunikasi dengan guru jika mengalami kesulitan dalam menyelesaikan suatu soal ataupun saat pembelajaran berlangsung. Produk ini juga dikemas dengan tampilan dan gambar-gambar yang relevan serta video yang menunjang pembelajaran, sehingga diharapkan dapat menarik minat siswa untuk belajar.

Berdasarkan uraian yang telah dikemukakan, maka penulis mengembangkan suatu produk berupa course ware berjudul "Pengembangan Website Berbasis Blended Learning dengan Materi Bangun Ruang Sisi Lengkung Kelas IX SMP". Penelitian ini bertujuan untuk menghasilkan dan mendeskripsikan kelayakan Website Berbasis Blended Learning dengan Materi Bangun Ruang Sisi Lengkung Kelas IX SMP yang telah dibuat.

\section{Metode}

Jenis penelitian ini adalah penelitian pengembangan. Proses penelitian pengembangan diawali dengan adanya permasalahan yang membutuhkan pemecahan dengan menggunakan suatu produk tertentu. Produk yang dimaksud adalah website berbasis blended learning dengan materi bangun ruang sisi lengkung kelas IX SMP. Pengembangan website berbasis 
blended learning ini menggunakan model pengembangan Thiagarajan. Model ini meliputi tahapan Define (tahap pendefinisian), Design (tahap perancangan), Develop (tahap pengembangan) dan Disseminate (tahap penyebaran). Akan tetapi pada pengembangan ini, penulis tidak menggunakan tahap disseminate karena keterbatasan waktu dan biaya.

Tahap Define merupakan tahap untuk menetapkan dan mendefinisikan keperluan pengembangan. Langkah-langkah pada define adalah (1) Tahap analisis kurikulum yaitu kurikulum yang digunakan adalah KTSP (Kurikulum Tingkat Satuan Pendidikan). Prinsip pelaksanaan dari kurikulum tingkat satuan pendidikan adalah kurikulum dilaksanakan dengan menggunakan pendekatan multistrategi dan multimedia dengan menyesuaikan keadaan sekolah masing-masing, (2) Tahap analisis karakteristik peserta didik yaitu berdasarkan observasi, siswa SMP Negeri 3 Malang merupakan siswa yang memiliki tingkat pendidikan yang tinggi. Selain itu siswa SMP Negeri 3 Malang juga memiliki fasilitas individu yang memadai. Disetiap waktu luang siswa selalu menyempatkan diri untuk memanfaatkan wifi yang ada untuk browsing, akan tetapi mereka lebih suka untuk membuka sosial media seperti facebook dan twitter, (3) Tahap identifikasi standar kompetensi, kompetensi dasar, dan indikator kompetensi pembelajaran yaitu tandar kompetensi dan kompetensi dasar yang dijadikan sebagai acuan dalam pengembangan website berbasis blended learning ini, disesuaikan dengan Peraturan Menteri Pendidikan Nasional tahun 2006, yaitu standar kompetensi memahami sifat-sifat tabung, kerucut dan bola, serta menentukan ukurannya. Sedangkan kompetensi dasarnya adalah mengidentifikasi unsur-unsur tabung, kerucut dan bola, menghitung luas selimut dan volume tabung, kerucut dan bola, dan memecahkan masalah yang berkaitan dengan tabung, kerucut dan bola, (4) merumuskan tujuan.

Tahap design bertujuan untuk merancang bahan-bahan dasar dari website yang dikembangkan. Langkah-langkah yang terdapat pada design adalah (1) Tahap Constructing criterion-referenced test adalah tahap mengubah tujuan pembelajaran yang dicantumkan ke dalam sebuah skema yang akan dikembangkan. Skema tersebut dikembangkan menjadi kerangka pengembangan. Kerangka pengembangan website berbasis blended learning dibentuk dalam struktur program dan storyboard. (2) Tahap Media selection adalah penentuan media yang tepat sebagai penyajian isi materi pembelajaran, (3) Tahap Format selection adalah tahap pemilihan format disesuaikan dengan media yang akan digunakan, (4) Tahap Initial design adalah penyajian bahan-bahan website berbasis blended learning yang tepat dan berurutan. Kegiatan tersebut merupakan draf desain yang sudah jadi sebelum divalidasi.

Tahap develop bertujuan untuk membuat rancangan awal dari bahan yang telah disusun dan merupakan langkah penyempurnaan dari langkah sebelumnya. Dalam tahap ini diberikan umpan balik kemudian dilakukan perbaikan pada website berbasis blended learning tersebut. Langkah-langkah yang terdapat pada develop adalah sebagai berikut (1) Tahap Expert appraisal merupakan suatu teknik untuk memvalidasi rancangan produk yang telah dirancang. Validasi tersebut dilakukan oleh orang yang ahli dibidangnya. Website berbasis blended learning divalidasi oleh ahli materi dan media, (2) Tahap developmental testing merupakan uji coba rancangan produk pada sasaran subjek yang sesungguhnya. Pada tahap ini subjek uji coba melibatkan 9 siswa SMP Negeri 3 Malang.

Uji coba yang telah dilakukan dapat diuraikan sebagai usaha untuk mengenali kesulitan siswa dalam menerima materi dengan menggunakan website berbasis blended learning yang 
dikembangkan. Produk pengembangan direvisi dengan memperhatikan saran dan kritik dari para ahli, siswa, dan guru pada saat validasi dan uji coba dilaksanakan. Revisi dilakukan dengan tujuan agar website berbasis blended learning yang dikembangkan dapat memenuhi standar kompetensi, kompetensi dasar, dan indikator yang telah dirumuskan.

Data yang diperoleh dari uji coba berupa data kuantitatif yang diperoleh dari skor angket validasi dan data kualitatif berupa data kritik dan saran yang diberikan oleh responden dari validasi website berbasis blended learning. Teknik analisis data yang digunakan untuk mengolah data hasil uji ahli dan uji kelompok kecil adalah teknik analisis persentase. Adapun rumus yang digunakan untuk mengolah data hasil validasi subjek uji coba adalah sebagai berikut.

Rumus yang digunakan adalah

$$
P=\frac{\sum x}{\sum x_{i}} \times 100 \%
$$

Keterangan:

$$
\begin{array}{ll}
\mathrm{P} & =\text { persentase kevalidan } \\
\Sigma \mathrm{x} & =\text { jumlah jawaban validator dalam satu item } \mathrm{x} \\
\Sigma \mathrm{xi} & =\text { jumlah jawaban maksimum dalam satu item } \\
100 \% & =\text { konstanta }
\end{array}
$$

Penentuan kesimpulan kevalidan website berbasis blended learning, digunakan kualifikasi tingkat kelayakan dengan kriteria pada Tabel 1.

Tabel 1. Kriteria Tingkat Kelayakan

\begin{tabular}{llll}
\hline Katagori & $\begin{array}{l}\text { Rentangan } \\
\text { Persentase }\end{array}$ & Kualifikasi & Ekuivalen \\
\hline A & $75 \%-100 \%$ & Valid & Layak \\
B & $50 \%-74 \%$ & Cukup Valid & Cukup Layak \\
C & $25 \%-49 \%$ & Kurang Valid & Kurang Layak \\
D & $0 \%-24 \%$ & Tidak Valid & Tidak Layak \\
\hline
\end{tabular}

(Sumber: Arikunto, 1990)

Setelah kita mengetahui suatu item masuk dalam kriteria valid atau cukup valid atau kurang valid atau tidak valid, kita harus memutuskan apakah item tersebut direvisi atau tidak. Adanya saran dari validator juga menentukan keputusan untuk merevisi sebuah produk hasil pengembangan. Berikut ini diberikan beberapa penjelasan yang terkait dengan hal tersebut: (a) jika suatu item dalam produk pengembangan masuk dalam kriteria valid/ layak, maka item tersebut tidak perlu direvisi kecuali ada saran dari validator untuk melakukan revisi, (b) jika suatu item dalam produk pengembangan masuk dalam kriteria cukup valid, maka item tersebut bisa direvisi atau tidak dengan memperhatikan hal-hal tertentu. Apabila ada validator yang memberikan saran, maka saran tersebut dapat digunakan sebagai pertimbangan dalam melakukan revisi, (c) jika suatu item dalam produk pengembangan masuk dalam kriteria kurang valid, maka item tersebut harus direvisi dengan memperhatikan hal-hal tertentu. Apabila ada validator yang memberikan saran, maka saran tersebut dapat digunakan sebagai pertimbangan dalam melakukan revisi dan (d) jika suatu 
item dalam produk pengembangan masuk dalam kriteria tidak valid, maka item tersebut harus diganti.

\section{Hasil dan Pembahasan}

Ahli materi website berbasis blended learning pada materi bangun ruang sisi lengkung kelas IX SMP adalah salah satu guru matematika SMP Negeri 3 Malang yang memiliki keahlian dalam melaksanakan pembelajaran yaitu Bapak Isbadar Nursit, M. Pd.

Analisis hasil validasi ahli materi ditunjukkan pada Tabel 2.

Tabel 2. Analisis Hasil Validasi Ahli Materi

\begin{tabular}{|c|c|c|c|c|c|}
\hline No. & Komponen yang Dinilai & $\sum \mathrm{X}$ & $\mathbf{X i}$ & $\begin{array}{l}\text { Persentase } \\
(\%)\end{array}$ & Keterangan \\
\hline 1. & $\begin{array}{l}\text { Pengorganisasian Isi } \\
\text { Pembelajaran }\end{array}$ & 24 & 24 & 100 & Valid \\
\hline 2. & $\begin{array}{l}\text { Penyajian Isi Materi } \\
\text { Pembelajaran }\end{array}$ & 67 & 68 & 98,5 & Valid \\
\hline 3. & Kelayakan Isi & 33 & 36 & 91,7 & Valid \\
\hline 4. & Silabus & 100 & 104 & 96,2 & Valid \\
\hline 5. & $\begin{array}{l}\text { Rencana Pelaksanaan } \\
\text { Pembelajaran }\end{array}$ & 188 & 192 & 97,9 & Valid \\
\hline 6. & $\begin{array}{l}\text { Lembar Kegiatan Siswa } \\
\text { (Unsur-unsur Tabung, } \\
\text { Kerucut, dan Bola) }\end{array}$ & 24 & 24 & 100 & Valid \\
\hline 7. & $\begin{array}{l}\text { Lembar Kegiatan Siswa } \\
\text { (Luas Permukaan Tabung, } \\
\text { Kerucut, dan Bola) }\end{array}$ & 24 & 24 & 100 & Valid \\
\hline 8. & $\begin{array}{l}\text { Lembar Kegiatan Siswa } \\
\text { (Volume Tabung, Kerucut, } \\
\text { dan Bola) }\end{array}$ & 24 & 24 & 100 & Valid \\
\hline \multirow[t]{2}{*}{9.} & Rubrik Penilaian & 23 & 24 & 95,8 & Valid \\
\hline & Rata-rata & 507 & 520 & 97,5 & Valid \\
\hline
\end{tabular}

Berdasarkan Tabel 2 setelah dilakukan penghitungan diperoleh rata-rata kevalidan materi website berbasis blended learning sebesar 97,5\%. Persentase tersebut menunjukkan bahwa secara keseluruhan materi website berbasis blended learning termasuk kategori valid atau layak sehingga tidak perlu diadakan revisi dan tetap bisa digunakan. Selain itu Ahli materi juga memberikan kritik dan saran seperti pembahasan latihan soal harus lebih rinci, kapasitas video yang digunakan jangan terlalu besar agar video mudah untuk di akses, tingkat kesulitan soal dimulai dari yang mudah, dan lengkapi rubrik penilaian dengan rentang nilai.

Ahli media website berbasis blended learning dengan materi bangun ruang sisi lengkung kelas IX SMP adalah satu dosen matematika Universitas Negeri Malang yaitu Ibu Dra. Susy Kuspambudi Andaini, M.Kom. Analisis hasil validasi ahli media ditunjukkan pada Tabel 3. 
Tabel 3 Analisis Hasil Validasi Ahli Media

\begin{tabular}{clcccc}
\hline No. & Hal yang Dinilai & $\sum \mathrm{X}$ & $\mathrm{Xi}$ & $\begin{array}{l}\text { Persenta } \\
\text { se (\%) }\end{array}$ & $\begin{array}{l}\text { Keteranga } \\
\mathrm{n}\end{array}$ \\
\hline 1. & $\begin{array}{l}\text { Pengorganisasian Isi } \\
\text { Pembelajaran }\end{array}$ & 21 & 24 & 87,5 & Valid \\
\hline 2. & $\begin{array}{l}\text { Penyajian Isi Materi } \\
\text { Pembelajaran }\end{array}$ & 58 & 64 & 90,6 & Valid \\
\hline 3. & Kelayakan Isi & 29 & 36 & 80,5 & Valid \\
\hline 4. & Pemilihan Media & 17 & 20 & 85 & Valid \\
\hline 5. & Desain Penyajian & 15 & 16 & 93,8 & Valid \\
\hline 6. & Teknologi & 13 & 16 & 81,3 & Valid \\
\hline & Jumlah & 153 & 176 & 86,9 & Valid \\
\hline
\end{tabular}

Berdasarkan Tabel 3, setelah dilakukan penghitungan diperoleh rata-rata kevalidan tampilan dan pengorganisasian fitur-fitur yang ada pada website berbasis blended learning sebesar 86,9\%. Persentase tersebut menunjukkan bahwa secara keseluruhan tampilan dan pengorganisasian fitur-fitur website berbasis blended learning termasuk kategori valid atau layak sehingga tidak perlu diadakan revisi dan tetap bisa digunakan. Beberapa kritik dan saran yang diberikan oleh Ahli media adalah pemberian soal latihan harus bertahap, tampilan sebaiknya juga harus bertahap, dalam video ada animasi yang tidak ada maknanya dan sebaiknya animasi tersebut diperjelas maknanya, belum ada petunjuk penggunaan, pengolahan menu di samping perlu disempurnakan, menu setting sebaiknya tidak perlu ada fasilitas edit.

Pengguna website berbasis blended learning pada materi bangun ruang sisi lengkung kelas IX SMP adalah 9 siswa kelas IX SMP Negeri 3 Malang. Hasil validasi angket digunakan untuk mengetahui penilaian siswa sebagai subjek sasaran penggunaan website berbasis blended learning pada materi bangun ruang sisi lengkung kelas IX SMP. Analisis hasil angket uji coba website berbasis blended learning dapt dilihat pada Tabel 4.

Tabel 4. Hasil Uji Coba oleh Pengguna

\begin{tabular}{llll}
\hline No. & \multicolumn{1}{c}{ Komponen yang dinilai } & Rata-rata (\%) & Kriteria \\
\hline 1. & Kualitas website berbasis website & 93,9 & Valid \\
2. & $\begin{array}{l}\text { Penyajian materi unsur-unsur bangun } \\
\text { ruang sisi lengkung }\end{array}$ & 89,6 & Valid \\
3. & $\begin{array}{l}\text { Penyajian materi luas permukaan bangun } \\
\text { ruang sisi lengkung }\end{array}$ & 90,8 & Valid \\
4. & $\begin{array}{l}\text { Penyajian materi volume bangun ruang sisi } \\
\text { lengkung }\end{array}$ & 90,6 & Valid \\
5. & $\begin{array}{l}\text { Penyajian latihan soal } \\
\text { 6. }\end{array}$ & 88,9 & Valid \\
& Keefektifan website berbasis website & 92,2 & Valid \\
& Rerata & 91 & Valid \\
\hline
\end{tabular}

Berdasarkan Tabel 4. persentase tingkat kevalidan website berbasis blended learning diperoleh sebesar $91 \%$. Persentase tersebut menunjukkan bahwa secara keseluruhan website berbasis blended learning termasuk kategori valid atau layak sehingga tidak perlu diadakan revisi dan tetap bisa digunakan.Kritik dan saran yang diberikan oleh responden uji coba, yaitu sebaiknya website diberi warna yang lebih menarik agar siswa semakin senang menggunakan website ini., materi yang tertulis sebaiknya lebih diperjelas agar siswa mampu 
dengan cepat menangkap tujuan pembelajaran, penggunaan kalimat pada website harus diperjelas lagi, latihan soal harus diperbanyak, kalimat-kalimat pada soal harus diperjelas, materi lebih diperbanyak sehingga dapat menunjang pembelajaran di sekolah, dan ada kunci jawaban yang tidak sesuai.

Dari hasil analisis hasil validasi dan analisis hasil uji coba, website berbasis blended learning secara keseluruhan dapat dikatakan valid, sehingga tidak perlu melakukan revisi dan layak untuk digunakan. Namun, dengan mempertimbangkan komentar dan saran, baik dari validator ahli materi, ahli media, maupun responden uji coba, penulis merasakan bahwa perlu adanya revisi produk. Revisi tersebut tidak bersifat keseluruhan, tetapi hanya beberapa bagian dari website yang dirasa perlu ditambah atau diperbaiki. Revisi produk dilakukan berdasarkan komentar dan saran yang diberikan validator ataupun responden uji coba.

\section{Simpulan}

\subsection{Kesimpulan}

Berdasarkan hasil analisis hasil validasi dan analisis hasil uji coba, website berbasis blended learning secara keseluruhan dapat dikatakan valid, sehingga tidak perlu melakukan revisi dan layak untuk digunakan guru sebagai alat bantu pembelajaran. Selain itu, website berbasis blended learning membantu siswa belajar mandiri dan memberikan pengalaman pembelajaran yang baru dengan menggunakan teknologi terkini. Fitur chat room yang ada pada website berbasis blended learning dapat mempermudah interaksi antara siswa dengan guru atau siswa dengan siswa karena dapat dilakukan di mana saja dan kapan saja dan juga fitur forum diskusi yang dapat melatih siswa untuk mengemukakan pendapat serta mendapat informasi dari siswa yang lain.

\subsection{Saran}

Saran pemanfaatan produk website berbasis blended learning diantaranya adalah sebelum melakukan pembelajaran dengan menggunakan website berbasis blended learning perlu dikaji terlebih dahulu tentang kesiapan siswa dalam hal ketersediaan laptop dan alat penghubung dengan internet serta kemampuan siswa dalam mengakses internet, sebelum pembelajaran berlangsung sebaiknya guru dan siswa telah mengetahui cara penggunaan website berbasis blended learning tersebut, pada implementasi pembelajaran dengan menggunakan website berbasis blended learning diperlukan kesiapan guru pengampu dalam hal kemampuan menyelenggarakan blended learning.

Saran diseminasi pada produk website berbasis blended learning pada materi bangun ruang sisi lengkung kelas IX SMP di antaranya adalah pihak sekolah memberikan pelatihan untuk memanfaatkan website berbasis blended learning dalam pembelajaran, sehingga guru tidak kesulitan dalam pengaplikasiannya saat pembelajaran. Selain itu pihak sekolah juga menyediakan fasilitas akses internet yang lebih baik sehingga dapat mempercepat proses akses website berbasis blended learning pada materi bangun ruang sisi lengkung kelas IX SMP.

Saran pengembangan produk website berbasis blended learning pada materi bangun ruang sisi lengkung kelas IX SMP diataranya adalah perlu dilaksanakan uji coba skala besar untuk mengetahui tingkat keakuratan kevalidan dengan data yang banyak sehingga produk dapat dimanfaatkan secara luas oleh kalangan pendidik. Untuk pengembang produk yang 
akan datang disarankan untuk menambahkan materi matematika yang lain atau pelajaran selain matematika. Selain itu disarankan untuk adanya penelitian lebih lanjut tentang efektivitas penggunaan produk website berbasis blended learning terhadap motivasi dan hasil belajar siswa.

\section{Daftar Rujukan}

Arikunto, S. (1990). Manajemen penelitian. Jakarata: Rineka Cipta.

Kusairi, S. (2011). Implementasi blended learning. Makalah disajikan dalam Seminar Nasional 2011 Pengembangan Pembelajaran Berbasis Blended Learning, Jurusan Biologi, FMIPA UM, Malang, 13 November.

Pragaswati, Rifqi H. (2012). Pengembangan website berbahasa inggris pada pembelajaran biologi berbasis blended learning materi sistem reproduksi manusia di SMA Negeri 5 Malang. Skripsi tidak diterbitkan. Malang: Universitas Negeri Malang.

Setyaningsih, R., Setyaningsih, N., \& Sutarni, S. (2011). Peningkatan pemahaman konsep geometri dan pengukuran dengan pendekatan kontekstual melalui pemanfaatan barang bekas sebagai media pembelajaran.

Susilo, H. (2011, November). Blended learning untuk menyiapkan siswa hidup di abad 21. In Makalah disajikan dalam Seminar Nasional.

Thiagarajan, S. (1974). Instructional development for training teachers of exceptional children: A sourcebook. 